\title{
Analyzing the Revitalization Strategies of Historical Fabric with the Approach of Endogenous Development Case Study (1, 2 \& 3 Regional of Zahedan City)
}

\author{
Mahsume Hafez Rezazade*, Razieh Islami Rad, Fatemeh Hashemzehi \\ Department of Geography and Urban Planning, Faculty of Human Science, Zahehan Branch, Islamic Azad \\ University, Zahedan, Iran \\ Email: *m_hafezrezazade2014@yahoo.com
}

Received 2 March 2016; accepted 14 June 2016; published 17 June 2016

Copyright (C) 2016 by authors and Scientific Research Publishing Inc.

This work is licensed under the Creative Commons Attribution International License (CC BY). http://creativecommons.org/licenses/by/4.0/

(c) (i) Open Access

\begin{abstract}
Internal development is applying of all the power and existing potential and actual capacities in the city to achieve sustainable and urban participation, and improves all social, physical, economic, and political structures to achieve a sustainable quality and quantity equilibrium. The policy of urban development in the world is to improve the productivity and optimization of land use and the possibility of infill development and improving access of city distressed fabric habitants to urban and social services. In this regard, the present study of Analysis of vitalization strategies of historical fabric with the approach of endogenous development Case study $(1,2$ \& 3 regional of Zahedan city). The research method is analytic-descriptive and based on library, documentary and field studies and VIKOR model has been also used for data analysis. Based on the results of VIKOR model, the 3 regional of Zahedan city with score 3 and the region 1 with a score of 0.436 were located on the highest and lowest rank. At the end, we suggested strategies according of the research result.
\end{abstract}

\section{Keywords}

Historical Fabrics, Endogenous Development, Zahedan City

\section{Introduction}

The rapid development of the city, in recent decades, has affected various social, economic, cultural aspects of human life. Proposed as the main slogan of the third millennium, the sustainable development is caused by the

${ }^{*}$ Corresponding author.

How to cite this paper: Rezazade, M.H., Rad, R.I. and Hashemzehi, F. (2016) Analyzing the Revitalization Strategies of Historical Fabric with the Approach of Endogenous Development Case Study (1, 2 \& 3 Regional of Zahedan City). Open Journal of Geology, 6, 363-371. http://dx.doi.org/10.4236/ojg.2016.66031 
impact of cities on the biosphere and on the different aspects of and human life [1]. Sustainable development and sustainable urban development in recent decades have been gradually changed to the new and dominant paradigm in the current scientific and theoretical literature on development and urban planning [2], which is a basis for improving overall health and long-term economic, social, physical, cultural and management sustainability [3]. The reliability of the development in an urban community is guaranteed when the urbanization is able to provide a desirable level of the economic production and the norm of employment rate, social welfare of high level of living in the city is formed, and a healthy life is flowing in a clean and green environment away from pollution concerns and with a high quality. Then it can be claimed that the urban reliable development and dynamic socio-economic and environmental development have been occurred because cities are passing a life cycle on the way of their evolutionary life cycle, so that they are born, grown, their quality increases, they will grow and their roles will be changed and finally, they will become old. In this regard, for maintaining the dignity and identity of the city in an effort to sustain and keep the city's urban fabric, especially of old tissues, the man does some actions that the endogenous development is one of these actions [4]. Today, many theories of physical development such as smart growth-intensive growth or development are moving in line with the ideas of sustainable development. Since internal development is a sub-category of sustainable development, if it will be considered it will bring economic and environmental benefits. In addition, it will heighten the quality of life, eliminate health threats, and can be associated with objects such as house making or job creation. Thus, it is not surprising that the governments interfere in this field all over the world although land prices increase and urban management issues will be followed by it. The endogenous development is the use of all potential and actual capacities and powers which are existed in city to reach a sustainable and participatory city and it will upgrade all social, physical, political, economic structures to reach a sustainable quantitative and qualitative development. The limitation of city texture will be specified within the concept of internal development and the next developments will be within the existing boundaries of the city [5].

The endogenous development is a development which is determined within economy and by a system that leads the production process. Endogenous development is an independent development but it doesn't mean e a return to the past or solitude and isolation but it means relying on itself and interaction with the outside world. In models of neoclassical economics, technology has been considered as an exogenous factor in the production process and some of proposed neoclassical models have recently considered the endogenous technology as the foundation of their work. The theory of endogenous growth tries to assimilate Schumpeter's theory in relation with the creation of endogenous knowledge with models of the neoclassical growth.

Internal growth is not means abandoning external areas of town; but also it seeks to regulate them. A discipline created a harmonious distribution of urban facilities and equipment in inside and outside areas of urban. The equilibrium and balance will help to create the internal and external consistency, in the old and new world, for today and tomorrow. Endogenous development is not tangible and known in our planning system. In recent years, in most cases, the purpose of urban development is the periphery development. While the problems associated with this type of development, imposes such high costs to city that for years it will be uncompensated and will not be accompany by the return of any capital.

\section{Research Purposes}

- Identify and prioritize components and infill development indicators in the old fabricate of Zahedan city.

- Creation of development suitable pattern for development of historical fabricate.

- Creation of a comprehensive mentality among city managers about the importance and necessity of urban infill development.

\section{Theoretically Basic}

\subsection{Urban Internal Development}

Cities are dynamic and social institutions, which can consider them similar to living organisms, which always in its evolution will pass physical life cycle, are created, growing, expanding, and evolving, frequently repeat of this cycle reflect the dynamics of the city physical space. Simultaneously with continuation of the cities life cycle, the urban elements are changed Emerged, their quantity are increased, and are changed the shape, at least maybe some be old. These changes are applied in all the city elements even areas and residential neighborhoods 
[6]. The structure of ancient cities is the lasting phenomenon and had talent and the power of life [7]. To prevent the death of city fabrics must emphasize its revitalization properties and restoration of its distressed fabrics [8]. Meanwhile, human provide actions to maintain the city identity in order to sustain and keep alive the city especially the old fabric that infill development is one case of this options. Because today, is expending the distressed areas of urban and in this regard, different approaches with backing to endogenous development principle are follow the revitalization of lost urban regionals. This principle does not search the writing way in expensive architecture, rapid unplanned roads, and a massive and rapid urbanization in an extensive range. Generally, the mentioned principle follows the cases such as, reconstruction of historic areas, use of the native city, and use of native urban design, use of mixed land use, giving priority to public transport and pedestrian traffic, attraction of local participation and giving attention to legacy of these fabrics [9]. Urban endogenous development with the use of capacities and opportunities based on urban planning emphasized on creating balance in the qualitative and quantitative distribution of the population, coordination among foundations of social life and escape from urban poverty and, ultimately, the use of public participation and social dynamics [5]. The internal growth is not means abandoning outer areas of town; rather than its seeking to regulate them, and create equilibrium, and harmonious distribution of urban facilities and equipment in the inside and outside of cities. The equilibrium caused internal and external adaptation of urban regionals. About the internal development, have been presented several definitions, some of these definitions are mentioned below:

The development of vacant land plots and non-use buildings that often are located in developed areas, called the internal development. Actually, the internal development, is the modernization, rehabilitation, and re-usable of urban areas [10], fair equal distribution of buildings and facilities in all areas and levels, security and the possibility of restructuring and reorganization of the city's fabric.

Successfully the internal development connects the new structures to the urban base, increasing the urban usefulness, and attempts to consider the available facilities and building the future together [11].

Internal development is the economical use of the existing vacant land in urban developed regions. Where that exist the services and facilities such as water, sewage system, road access, public transport or there are a number of these facilities. The internal development usually is the residential development on a plot of land that remained between buildings [12]. The internal development, is build the new buildings on vacant lots or unused parts of neighborhoods as well as commercial areas. These places are usually located in vicinity of where we live which already have enjoyed from infrastructure services, such as access roads, water, electricity, etc. By creating the internal development, can lead to the growth of living indicators and increasing quality of life in urban neighborhoods. Urban internal development is reinvestment in available urban areas or substantially development of useful sites in productivity. Redevelopment of non-use sites is the important strategy for improving the quality of life in urban cores, which reduce human risks and protect the arable land. However, in many cities, exist the large pieces of unused land within urban areas, and in term of stability new growth of urban areas can be channelize from urban periphery areas to unused and unexploited inside urban lands. The internal growth is not means abandoning outer areas of town; rather than it is seeking to regulate them, and create equilibrium, and harmonious distribution of urban facilities and equipment in the inside and outside of cities. The equilibrium caused internal and external adaptation of urban regionals.

\subsection{Endogenous Development Aims}

Several objectives in the field of endogenous development projects mentioned, that generally summarized in four major axes: Peripheral; Physically; Economic; Social.

\section{The Situation of the Area under the Study}

Zahedan is located in the province of Sistan and Baluchestan in southeast of Iran. It is bordering Afghanistan and Pakistan. Zahedan is the center of the province with an area of 5771 hectares and 2000 meters above the sea level (Figure 1). The area which Zahedan is situated on does not have identical topographical features. Hence, many urban problems are associated with the topographic of the region. Zahedan's topographic is mainly influenced by the surrounding mountains and vast plains.

In 2010, based on detailed design divisions of Zahedan city, Due to population growth and physical development of the city, regions of Zahedan increased from 3 regionals to 5 regionals. In the present research for the most accurate investigation, have been investigated the 1, 2 and 3 regional Zahedan city (Figure 2). 


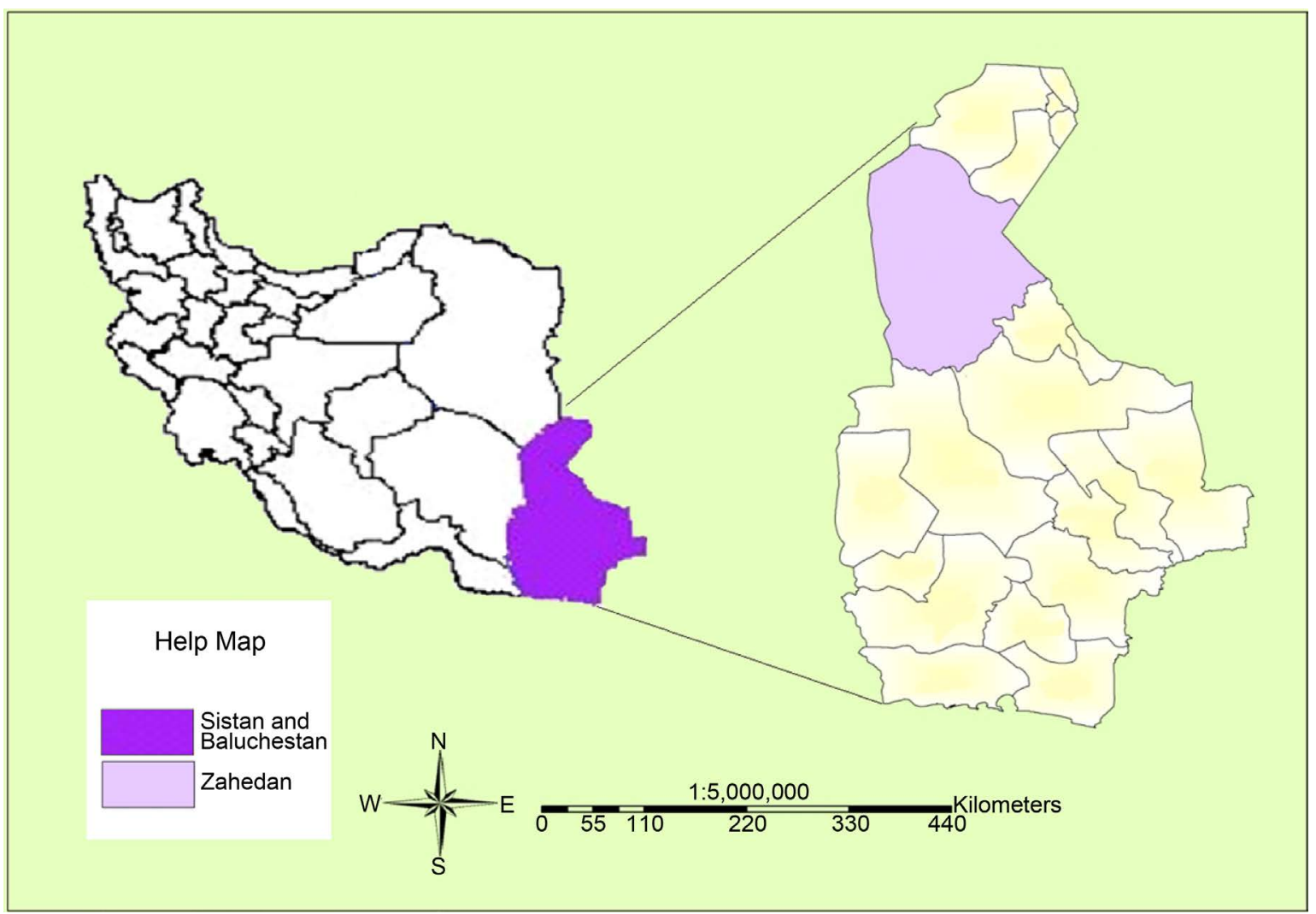

Figure 1. Map of the study area, Source: research findings.

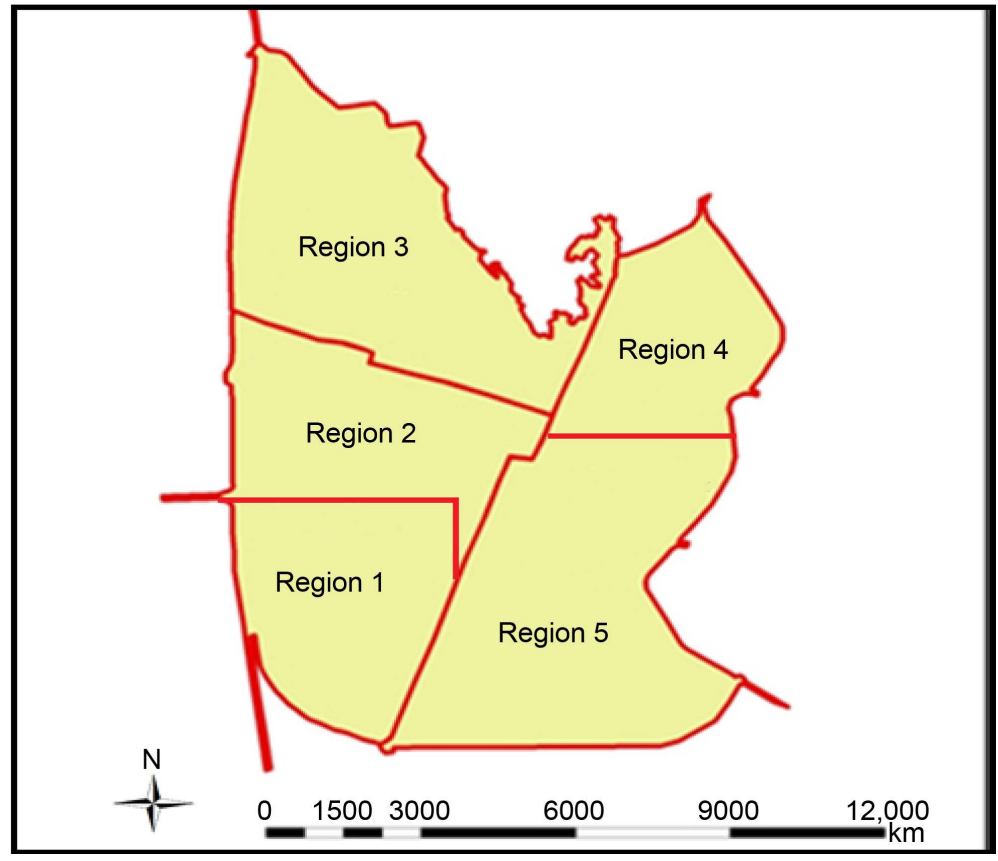

Figure 2. Map of the study area, Source: research findings.

\section{Research Methodology}

Methodology of the present research was the analytical-descriptive method and based on documental, library 
studies and field surveys. Also, according to the research aim, used of VIKOR model to data analysis.

\section{Discussion and Conclusion}

To investigation the internal development of old fabrics of Zahedan city, the number indicators in the social, economic, spatial, management, environmental, was regulated based on theoretically literature that is mentioned in Table 1.

\section{Stages of implementation model}

\section{First step:}

\section{Determination the weight of criteria}

To investigation of internal development of old fabric urban of Zahedan, due to high number of indicator, have been studied the dimensions. So that each of the respondents respond to questions exist on the questionnaires distributed based on the proposed indicators. Due to use of VIKOR model, the number of respondents are 20 people of city experts and managers.

The results of criteria and indicators as the crude data from the 1 to 10 were evaluated by experts (Table 2).

At this step used of likert scale to converting quantitative data to qualitative data (Table 3).

\section{Table 1. Components and indicators related to development within the urban old fabric of Zahedan.}

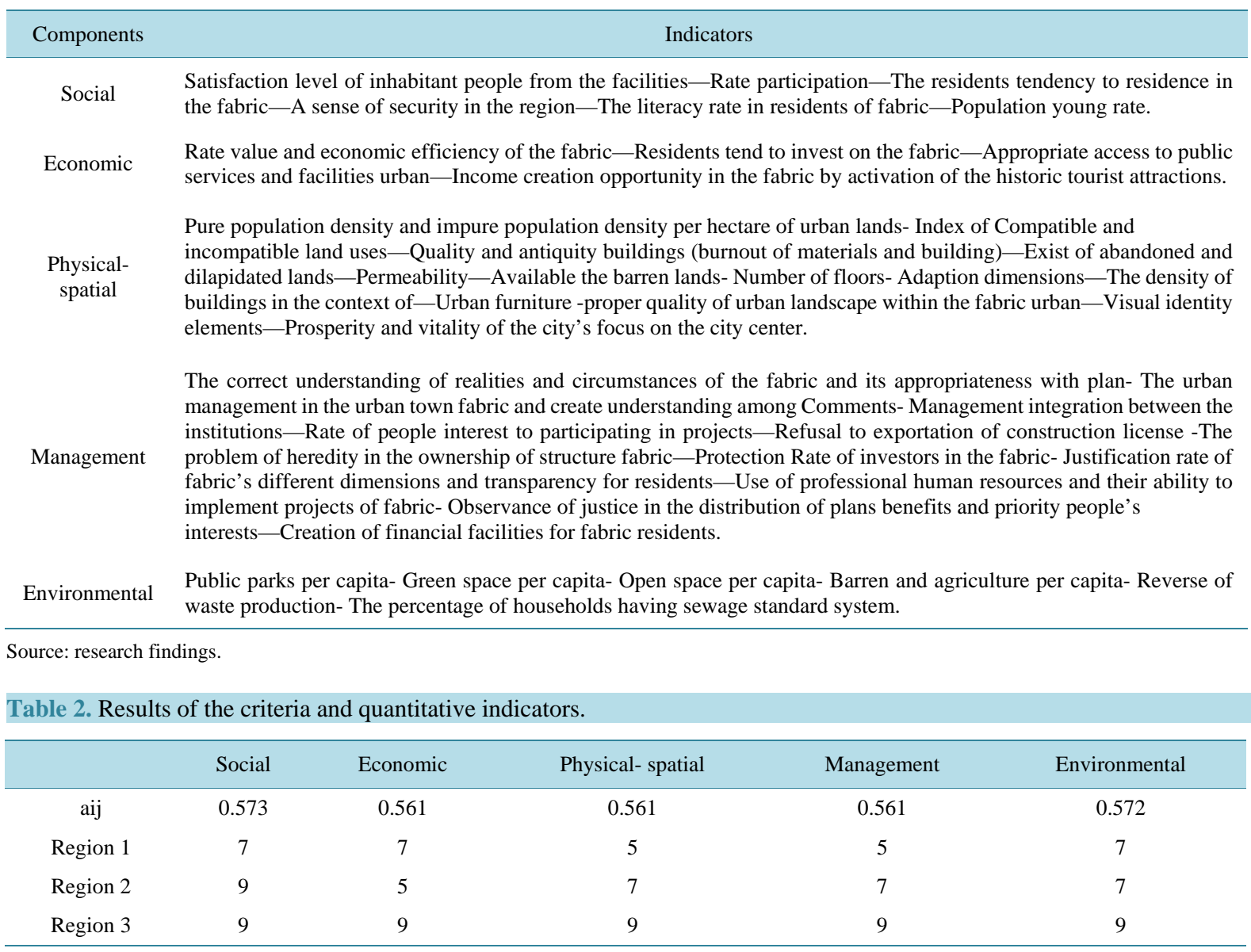

Source: research findings.

Table 3. Table rating likert scale.

\begin{tabular}{|c|c|c|c|c|c|c|c|c|c|c|}
\hline 0 & 1 & 2 & 3 & 4 & 5 & 6 & 7 & 8 & 9 & 10 \\
\hline & Very little & & little & & Average & & much & & Very much & \\
\hline
\end{tabular}

Source: research findings. 


\section{Second step:}

Normalization of the decision matrix:

$$
r_{i j}=\frac{X_{i j}}{\sqrt{\sum_{i=1}^{m} X_{i j}^{2}}}
$$

By using of above formula (1) first for all of the matrix values calculated the exponent 2 and calculated the sum of each column (Table 4). Then, obtained the square root of the sum of each column, finally, each value is divided on the square root (Table 5).

Third step:

Weighting of normal matrix

To weighting of normal matrix values, is multiplied each of the options, on weighting of criteria (which has already been obtained in other ways) (Table 6).

Fourth step:

Determining the highest and lowest values of normal weight matrix

Determined the largest and smallest value for each column (Table 7).

Table 4. Exponent 2 numbers.

\begin{tabular}{cccccc}
\hline & Social & Economic & Physical- spatial & Management & Environmental \\
\hline aij & 0.573 & 0.561 & 0.561 & 0.561 & 0.572 \\
Region 1 & 49 & 49 & 25 & 25 & 49 \\
Region 2 & 81 & 25 & 49 & 49 & 49 \\
Region 3 & 81 & 81 & 81 & 81 & 81 \\
$\sum$ & 211 & 155 & 155 & 155 & 179 \\
\hline
\end{tabular}

Source: research findings.

Table 5. Square root of the sum of each column and divide by the square root of the sum of each of the values.

\begin{tabular}{cccccc}
\hline & Social & Economic & Physical- spatial & Management & Environmental \\
\hline aij & 0.573 & 0.561 & 0.561 & 0.561 & 0.572 \\
Region 1 & 0.482 & 0.562 & 0.401 & 0.401 & 0.523 \\
Region 2 & 0.619 & 0.401 & 0.562 & 0.562 & 0.523 \\
Region 3 & 0.619 & 0.723 & 0.723 & 0.723 & 0.671 \\
\hline
\end{tabular}

Source: research findings.

Table 6. Weighting of normal matrix.

\begin{tabular}{cccccc}
\hline & Social & Economic & Physical- spatial & Management & Environmental \\
aij & 0.573 & 0.561 & 0.561 & 0.561 & 0.572 \\
Region 1 & 0.277 & 0.315 & 0.225 & 0.225 & 0.315 \\
Region 2 & 0.356 & 0.224 & 0.315 & 0.298 & 0.406 \\
Region 3 & 0.355 & 0.406 & 0.406 & 0.384 & 0.25 \\
\hline
\end{tabular}

Source: research findings.

Table 7. Determining the highest and lowest values of normal weight matrix.

\begin{tabular}{clllll}
\hline f max & 0.356 & 0.406 & 0.406 & 0.406 & 0.384 \\
f min & 0.277 & 0.224 & 0.225 & 0.225 & 0.298 \\
f+ - F- & 0.082 & 0.182 & 0.181 & 0.181 & 0.086 \\
\hline
\end{tabular}

Source: research findings. 
At this stage, the highest value and lowest value of standard functions extracted from the decision matrix. Here the greatest number means a number that has the most positive value and the smallest Means most negative value. So if our criterion be type of negative, the largest number converted to the lowest and smallest number converted to the greatest value and vice versa.

$$
f_{i}^{*}=\max _{j} f_{i j} ; \quad f_{i}^{-}=\min _{j} f_{i j}
$$

\section{Fifth step:}

\section{Determine the Suitability index $(S)$ and repugnance index $(R)$ :}

At this step obtained the distance of each option to the ideal solution, then the sum of them calculated according to the following formula (Table 8). In other words, at this step after calculation normalized matrix and weighting matrix and extracting the highest and lowest value for each index in order to calculate of the VIKOR index (Which accordingly calculated our options) was calculated Suitability index and discomfort index.

$$
S_{j}=\sum_{i=1}^{n} w_{i} \cdot \frac{f_{i}^{*}-f_{i j}}{f_{i}^{*}-f_{i}^{-}} ; \quad R_{j}=\max _{i}\left[w_{i} \cdot \frac{f_{i}^{*}-f_{i j}}{f_{i}^{*}-f_{i}^{-}}\right]
$$

${ }^{*}=$ The biggest number of weighted normal matrix for each column

$f_{i j}=$ number of preferred option for each criterion in the weighted normal matrix

$f^{-}=$smallest number of weighted normal matrix for each column

For each criterion was obtained a Suitability index that the sum of them determines the final index of option.

The biggest $S_{j}$ of each option for each criterion, is the (dissatisfaction) repugnance index $(R)$ of that option.

\section{Sixth step:}

\section{Calculate the $Q$ amount and the final ranking of options}

In this step, the VIKOR index (that is the final score of any option) was calculated. $Q$ value reveals the final ranking of any organization from the studied parameters (Table 9). " $v$ " is the strategy Weight (the majority of criteria) or gregarious suitability maximum. The amount of " $s$ " reveals the distance from positive ideal solution of " $i$ " option. When $v$ is larger than 5.0, $Q$ index has maximum agreement. When $v$ is smaller than 5.0, reveals the maximum of negative attitude. Also options ranked based on $Q$ values. Options with greater value of $Q$, placed on larger rank. $Q$ values smallest placed on lower rank (by using the following formula).

$$
Q_{j}=v \cdot \frac{S_{j}-S^{-}}{S^{*}-S^{-}}+(1-v) \cdot \frac{R_{j}-R^{-}}{R^{*}-R^{-}}
$$

$v=$ constant number of $0 / 5$

$S_{j}=$ the sum of " $S$ " for each option

$S^{-}=$the largest number of " $S$ " index for each option

Table 8. Determine the suitability index $(S)$ and repugnance index $(R)$.

\begin{tabular}{cccccccc}
\hline & Social & Economic & Physical- spatial & Management & Environmental & \\
\hline aij & 0.573 & 0.561 & 0.561 & 0.561 & 0.572 & $S$ & $R$ \\
Region 1 & 0.079 & 0.091 & 0.181 & 0.181 & 0.084 & 0.616 & 0.181 \\
Region 2 & 0.000 & 0.224 & 0.091 & 0.091 & 0.084 & 0.049 & 0.224 \\
Region 3 & 0.000 & 0.000 & 0.000 & 0.000 & 0.000 & 0.001 & 0.001 \\
\hline
\end{tabular}

Source: research findings.

Table 9. Calculate the amount $Q$ and the final ranking options.

\begin{tabular}{ccc}
\hline regional & Weighted Score & Rank \\
\hline Region 1 & 0.436 & 2 \\
Region 2 & 0.096 & 3 \\
Region 3 & 1.000 & 1 \\
\hline
\end{tabular}

Source: research findings. 
$S^{*}=$ smallest number of " $S$ " index for each option

$R_{j}=$ the R-value sum for each option

$R^{-}=$the largest number of " $R$ " index $\mathrm{R}$ for each option

$R^{*}=$ the smallest number of " $R$ " index for each option

Finally, the $\mathrm{Q}$ value maximum is selected as the best option.

As the table shows, the largest number belongs to the three regional Zahedan city. This means that the region 3 of Zahedan city in the use of endogenous development indicators to reconstruction of historic urban fabrics has been more successful than other regions. As well as the region 1 with a score of 0.436 located on the second rank and the region 2 with score of 0.096 located on the last rank.

\section{Conclusion}

City is created by human thought and so on, in different societies, demonstrates the different appearance and landscape. Accordingly, the patterns, which are regulated to urban planning and organizing could not proposed a standard measure for all cities, with different culture conditions and natural properties. Therefore, on the designed plans for cities all economic, social, cultural dimensions must be considered, and find the appropriate response to all urban problems, with regard to the urban problems. So today decisions about urban problems due to the more complex relationships and reactions, require the special care and planning. The rapid social, economic, cultural, political development of the city on recent decades affected human life. Meanwhile, human provide actions to maintain the city identity in order to sustain and keep alive the city especially the old tissues that infill development is one case of this option. Because today, it is expending to the distressed areas of urban and in this regard, different approaches with backing to endogenous development principle are followed by the revitalization of distressed urban regionals. In this regard, the present study is the analysis of regeneration strategies of historical fabric with the approach of the endogenous development case study (1, 2 \& 3 regions of Zahedan city). The research method is analytic-descriptive and based on library, documentary and field studies and VIKOR model has been also used for data analysis. Based on the results of VIKOR model, the 3 regions of Zahedan city with score 3 and the region 1 with a score of 0.436 were located on the highest and lowest rank.

\section{Suggestions}

- Determine the optimal population centers of old texture of Zahedan considering the possibility of providing the essential needs of a dynamic monitoring and enforcement programs in this field.

- According to the current needs of the textures in the center of Old Town and prioritize them in providing municipal services to the urban areas.

- Centralized and unified management of the entire texture sites such as the Old Town City Hall Old Town Center and historic textures.

\section{References}

[1] Qerekhlu, M. and Hashemi, H. (2007) Indicators of Sustainable Urban Development. No. VIII, Journal of Geography and Regional Development, 157.

[2] Rahnemaie, M.T. and Pourmoosavi, S.M. (2007) Check Security Instabilities Based on the Sustainable Development of Metropolitan Tehran. Geographical Research, No. 5.

[3] Abdi, M.A., et al. (2011) The Development of Inner Cities. Building and Housing Research Press, 1-15.

[4] Mohammadi, J. (1996) Affecting Factors on the Cities Physical Development, The First Joint Seminar on Urban Planning and Historic Buildings. Zanjan University, Zanjan.

[5] Aiyni, M., et al. (2010) Improving Urban Land Productivity, Improve Outcomes and Renovation of Old Texture City. Economic Housing Magazine, No. 39, 48.

[6] Zangiabadi, A. (1992) Geography and Urban Planning of Kerman. Press Center of Kerman, volumes 1 and 2.

[7] Taban, M., et al. (2008) Reorganization the Identify Factors Dezfool Historic Fabrics and Its Application in the City Development. Quarterly Journal of City Management, No. 22.

[8] Motacef, N. (2007) The Comprehensive Revitalization and Development of Tehran Distressed Regions Is Inevitable Necessity. The Second Seminar on Construction in the Capital, Tehran University Press, Tehran.

[9] Refieian, M., et al. (2010) Identification the Predisposing Areas of Distressed Fabrics Creative Development with 
Tourist Approach in Urban Planning (Case Study: Emamzadeh Yahya Town, District 2, 12 Region of Tehran City). Quarterly Journal of City Management, No. 25.

[10] Varesi, H.R. (2004) Analysis the Historical Fabric of Esfahan City. Quarterly Journal of Culture, No. 27 and 28.

[11] EPA, United States Environmental Protection Agency (2004) Making Way for Urban Infill and Brown Field Redevelopment. John Wiley \& Sons, Hoboken.

[12] Saifuddini, F. (2000) Urban and Regional Planning Vocabularies. Shiraz University Press, Shiraz.

\section{Submit or recommend next manuscript to SCIRP and we will provide best service for you:}

Accepting pre-submission inquiries through Email, Facebook, Linkedin, Twitter, etc A wide selection of journals (inclusive of 9 subjects, more than 200 journals)

Providing a 24-hour high-quality service

User-friendly online submission system

Fair and swift peer-review system

Efficient typesetting and proofreading procedure

Display of the result of downloads and visits, as well as the number of cited articles

Maximum dissemination of your research work

Submit your manuscript at: http://papersubmission.scirp.org/ 